\title{
URBAN ECOLOGY DALAM RANGKA PENINGKATAN ENVIRONMENTAL AWARENESS DI KELURAHAN BIDARA CINA JAKARTA TIMUR.
}

\author{
Damianus Dai Koban \\ State University Of Jakarta \\ damianusdaikoban@gmail.com
}

\begin{abstract}
Abstrak
Penelitian bertujuan mengetahui bagaimana penerapan Urban Ecology dalam rangka peningkatan Environmental Awareness di Kelurahan Bidara Cina Jakarta Timur. Metode yang digunakan adalah metode deskriptif teoretik. Penelitian dilaksanakan pada bulan Januari hingga Mei 2018. Hasil Penelitian menunjukkan bahwa terdapat empat kendala dalam penerapan Urban Ecology dalam rangka peningkatan Environmental Awareness di Kelurahan Bidara Cina Jakarta Timur yakni, pertama kebutuhan akan lahan untuk warga urban sangat besar sekali, sehingga RTH menjadi kendala utama kerterbatasan lahan, kedua banyaknya urbanisasi warga pendatang yang menyebabkan populasi penduduk bertambah dari tahun ke tahun sehingga, lahan semakin terbatas, ketiga banyaknya generasi muda yang tidak sadar akan lingkungan, sehingga tidak mendukung gerakan kesadaran lingkungan, keempat kesibukan dari tokoh agama yang menyebabkan kurangnya kegiatan peribadatan sehingga sosialisasi tentang kesadaran lingkungan tidak dilakukan secara maksimal.
\end{abstract}

Keywords: Urban Ecology, Environmental Awareness.

\begin{abstract}
The research aims to find out how the application of Urban Ecology in order to increase Environmental Awareness in East Jakarta Bidara Cina. The method used is theoretical descriptive method. The study was conducted from January to May 2018. The results showed that there are four obstacles in the application of Urban Ecology in order to increase Environmental Awareness in East Jakarta Bidara namely, first the need for land for urban residents is very large, so that green space becomes the main obstacle limitation land, both the urbanization of the immigrant population causing the population to increase from year to year so that, the land is more limited, the third the number of young people who are not aware of the environment, so as not to support the movement of environmental awareness, the four busyness of religious leaders causing the lack of worship activities so that socialization on environmental awareness is not done maximally.
\end{abstract}

Keywords: Urban Ecology, Environmental Awareness. 


\section{PENDAHULUAN}

Perubahan iklim dan pemanasan global memiliki konsekuensi negatif bagi manusia dan alam. Dimana, dari tahun ke tahun semakin meningkat aktifitas kegiatan produksi manusia yang menyebabkan penurunan kualitas dari lingkungan itu sendiri yang menjadi sebuah konsekuensi terjadinya perubahan iklim. Untuk dapat mengatasi semua permasalahan lingkungan tersebut, diperlukan sebuah inovasi hijau untuk mengatasinya. Karenanya pentingnya adaptasi terhadap dampak perubahan iklim, dan penerapan tindakan pencegahan dalam mengatasi hal tersebut. Dimana sangat diperlukan sekali sebuah kesadaran dan pengetahuan yang komprehensif tentang permasalahan lingkungan itu sendiri.

Masalah lingkungan hidup sendiri telah dinyatakan sebagai masalah sosial yang penting disemua negara. Karena hampir disetiap negara telah membentuk sebuah strategi untuk permasalahan ini. Dan strategi tersebut adalah strategi lingkungan untuk pembangunan yang berkelanjutan. Dimana pembangunan berkelanjutan sendiri mempunyai konsep bahwa untuk dapat memenuhi kebutuhan masa kini tanpa mengorbankan kemampuan untuk generasi masa depan. Sehingga konsep pembangunan berkelanjutan ini merupakan solusi dalam mengatasi krisis lingkungan yang ada disetiap negara tersebut.

$$
\text { Meskipun }
$$

pembangunan berkelanjutan merupakan isu utama, namun masih banyak perdebatan politik dan ekonomi di seluruh dunia, tentang pergeseran paradigma tersebut. Dimana pergeseran yang signifikan tentang konsumsi dan produksi yang berkelanjutan terutama di negara - negara berkembang. Tantangan yang terjadi terutama untuk meyakinkan kelompok, komunitas, individu tentang paradigma berkelanjutan tersebut.

Sebagai contoh kasus - kasus di perkotaan merupakan kasus yang sangat terlihat penurunan kualitas lingkungan secara langsung, dimana kurang kesadaran dari kelompok, komunitas dan individu itu sendiri dalam mengelola lingkungan di sekitarnya. Karenanya pentingnya peningkatan kesadaran lingkungan disetiap individu dalam melakukan kegiatan yang bersentuhan dengan lingkungan alam tersebut. Dengan adanya peningkatan kesadaran ini merupakan titik awal untuk perubahan dari perilaku ramah terhadap lingkungan itu sendiri.

Karenanya jika semakin banyak individu atau komunitas yang memilki kesadaran lingkungan yang tinggi, maka akan menjadi sebuah gerakan baru untuk dukungan penuh terhadap kelestarian lingkungan tersebut. Sehingga terbentuklah sebuah program lingkungan yang berkelanjutan. Sehingga, berdasarkan latar belakang masalah diatas penulis mengangkat sebuah judul penelitian yaitu Urban Ecology 
dalam rangka peningkatan Environmental Awareness di Kelurahan Bidara Cina Jakarta Timur.

\section{METODOLOGI}

Metode yang digunakan dalam penelitian ini adalah metode deskriptif teoretik yakni penelitian yang bertujuan menjelaskan gambaran Urban Ecology dalam rangka peningkatan Environmental Awareness di Kelurahan Bidara Cina Jakarta Timur.

\section{HASIL DAN PEMBAHASAN}

Peran Lurah Bidara Cina sangat strategis sebagai pimpinan kelurahan yang memiliki wewenang yang berkaitan dengan wilayah domisili dalam hal pengambil keputusan terlebih untuk warga urban yang baru menempati lokasi atau wilayah yang ditempati di kelurahan tersebut. Selain lurah, diperlukan juga dewan Kelurahan yang memiliki peran yang lebih dekat dengan masyarakat sebagai ujung tombak dari lurah setempat. Sehingga, peran lurah dalam meningkatkan urban ecology lebih mudah tercapai bersama perangkat dewan kelurahan tersebut.

Peran Ketua RT terhadap urban ecology adalah sebagai pucuk pimpinan dalam RT tersebut, yang lebih mengetahui kondisi di lapangan, sehingga penerapan UU RTH ini lebih dipahami oleh masyarakat secara kelompok kecil.
Tokoh agama disini memberikan pencerahan kepada umat tentang pentingnya RTH yang merupakan bagian dari iman seseorang, dengan demikian umat lebih sadar akan pentingnya RTH tersebut. Sehingga, warga kadang lebih meyakini informasi yang disampaikan oleh tokoh agama sebagai public figure yang dipercayai berkaitan dengan kerohanian.

Kendala yang terjadi dalam penerapan enviromental awareness adalah pertama kebutuhan akan lahan untuk warga urban sangat besar sekali, sehingga RTH menjadi kendala utama kerterbatasan lahan, kedua banyaknya urbanisasi warga pendatang yang menyebabkan populasi penduduk bertambah dari tahun ke tahun sehingga, lahan semakin terbatas, ketiga banyaknya kaum muda yang tidak sadar akan lingkungan, sehingga tidak mendukung gerakan kesadaran lingkungan, keempat kesibukan dari tokoh agama yang menyebabkan kurangnya kegiatan peribadatan sehingga sosialisasi tentang kesadaran lingkungan tidak dilakukan secara maksimal.

Kurangnya kesadaran lingkungan dari warga di Kelurahan Bidara Cina yang menyebabkan pemakaian lahan terbuka hijau tidak pada tempatnya. Pemakaian lahan pekarangan rumah yang tidak sesuai dengan ketentuan uu tata lahan bahwa $30 \%$ harus digunakan untuk penanaman pohon atau tanaman hijau lainnya, tetapi malah digunakan untuk pekarangan dan kepentingan pribadi. 
Kemudian Pemeritah disini haruslah membuat rencana kebijakan yang tepat sasaran dalam rangka meningkatkan kesadaran lingkungan tersebut. Seperti, peran penting dalam menciptakan kesadaran di kalangan masyarakat dan generasi muda melalui kampanye, pamflet, diseminasi informasi, seminar dan lokakarya. Dan lebih penting lagi memberikan pelajaran dan pemahaman kesadaran lingkungan sejak sekolah dasar, dimana isu lingkungan haruslah menjadi bagian penting dalam kegiatan kurikulum. Karena kesadaran merupakan prasyarat positif untuk peningkatan terhadap masalah lingkungan. Apabila informasi diedarkan dan ditampilkan kepada generasi muda sehingga mereka lebih percaya diri dan bersedia bekerja sama dengan kegiatan peningkatan kesadaran lingkungan yang diusulkan atau dilaksanakan. Pengembangan strategi adaptasi produk dan teknologi hijau dan produk juga harus dilaksanakan dengan benar. Karena dengan penggunaan produk yang sudah ramah lingkungan maka akan membantu terciptanya kesadaran lingkungan secara positif. Sehingga dukungan penuh dari semua pihak yang terkait sangat penting disini. Walaupun penggunaan teknologi hijau ini masih memilki kendala karena biaya teknologi dan produk ini sangat tinggi jika dibandingkan dengan produk dan teknologi pengganti tradisional.Namun manfaat yang akan diterima justu lebih baik untuk jangka waktu yang akan datang. Karenanya pentingnya pendidikan lingkungan sebagai alat potensial untuk mengangkat pengetahuan, pemahaman dan kesadaran warga tentang kesadaran lingkungan tersebut. Karena manfaat yang akan didapatkan untuk generasi masa depan yang lebih baik.

\section{KESIMPULAN}

Penerapan Urban Ecology dengan fokus pada (Ruang Terbuka Hijau) RTH sangat diperlukan bagi setiap warga maupun umat yang berdomisili diwilayah Kelurahan Bidara Cina Jakarta Timur. Untuk mencapai hal ini diperlukan dukungan dari semua pihak yang terkait dalam penerapan Environmental Awareness secara berkelanjutan. Keberhasilan program ini juga diperlukan sosialiasi secara terus menerus agar masyarakat atau umat semakin sadar akan manfaatnya RTH tersebut. UU yang diperlakukan perlu dipahami secara bersama sehingga tidak merugikan khususnya warga perkotaan yang baru memulai usaha di lokasi tersebut, khususnya Kelurahan Bidara Cina.

\section{DAFTAR PUSTAKA}

Akhter, Shahima, and Piyush Malaviya, 2015, "Assesment of Environmental Awareness Among Rural and Urban Residents in Bishnah, Jammu, and Kashmir, India”. International Journal of Basic and Applied Science. Vol. 4, No. 3.

Dombrowski, U., Ernst, and A. Reimer, 2016, "A New Training fof Factory Planning Engineers to Create Awareness of 
Climate Change”. Procedia CIRP Journal Vol.48.

Endlicher, Wilfried, Patrick Hostert, Ingo Kowarik, Elmar Kulke, Julia Lossau, John Marzluff, Elke Van De Meer, Harald Mieg, Gunnar Nu'tzmann, Marlies Schulz, and Gerd Wessolek, 2011, "Perspective in Urban Ecology Studies of Ecosystems and Interaction between Human and Nature in the Metropolis of Berlin”, Berlin: Springer.

Endlicher, Wilfried, Marcel Langner, Markus Hesse, Harald A. Mieg, Ingo Kowarik, Patrick Hostert, Elmar Kulke, Gunnar Nützmann, Marlies Schulz, Elke van der Meer, Gerd Wessolek, and Claudia Wiegand, 2007, "Urban Ecology Definitions and Concepts". Researchgate Journal.

Gomez, Francisco Gonzalez, 2016, "Do Pro Environmental Behaviors and Awareness Contribute to Improve Subjective Well Being?". Applied Research Quality Life Journal. Vol.11.

Ham, Marija, Dajana Mrcela, and Martina Horvat, 2016, "Insights for Measuring Environmental Awareness”. Environmental Journal.p.160-161.

Kamruddin, Siti Mazwin, Puziah Ahmad, and Norsyamira Alwee, 2016, "Community Awareness on Environmental Management Through Local Agenda 21 (LA21)". Procedia Social and Behavioral Science Journal. Vol. 222,p.731-737.

Niemela, Jari, 2011, "Urban Ecology Pattern, Processes, and Application”, New York: Oxford University Press.

Pickett, S.T.A., M.L.Cadenasso, and Brian McGrath, 2013, "Resilence in Ecology and Urban Design Linking Theory and Practice for Sustainable Cities", New York: Springer.

Piekarski, Wieslaw, Monika Stoma, Agnieszka Dudziak, Dariuz Andrejko, and Beata Slaska Grzywna, 2016, "How Location Shapes Environmental Awareness Among Inhabitants of Eastern Poland An Empirical Study". Journal Pol. Environment Studies. Vol. 25, No. 2.

Rafika, Kortri, Kalli Rym, Sassi Boudmagh Souad, and Lazri Youcef, 2016, " $A$ Public Actor Awareness for Sustainable Development". Procedia Social and Behavioral Sciences. Vol. 216.

Rahman, Mazni Adibah Abd, and M. Zainora Asmawi, 2016, "Local Residents Awareness Towards the Issue of Mangrove Degradation in Kuala Selangor, Malaysia”. Procedia Social and Behavioral Sciences. Vol. 216.

Roeder, Ina, Matthias Scheibleger, and Ing Rainer Stark, 2016, "How to Make People Make a Change Using Social Labelling for Raising Awareness on Sustainable Manufacturing”. Procedia CIRP Journal. Vol.40.

Saifullah, Md. Khaled, Fatimah Binti Kari, and Md. Arphan Ali, 2017, "Linkage Between Public Policy, Green Technology, and Green Products on Environmental Awareness in the Urban Kuala Lumpur, Malaysia”. Journal of Asian Finance Economic and Business. Vol. 4, No. 2.

Shivakumara, K., Sangeetha R. Mane, J. Diksha, and O. Nagaraj, 2015, "Effect of Gender on Environmental Awareness of Post Graduate Students". British Journal of Education, Society \& Behavioral Science Vol.48.No.1. 